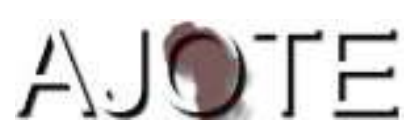

Africa Journal of Teacher Education

ISSN 1916-7822. A Journal of Spread Corporation

Vol.6 No. $1 \quad 2017 \quad$ Pages 39-55

\title{
Challenges in Ethiopian Teacher Education Pedagogy: Resistance Factors to Innovative Teaching-Learning Practices
}

\section{Abiy Zewdu Agegnehu}

(abiyzewd@gmail.com)

\begin{abstract}
Quality is at the heart of any education and training system. It influences what trainees learn, how well they learn and what benefits they draw from their education and training. Whether a particular education and training system is of high or low quality can be judged in terms of input, output and process. Until recently, however, much discussion of educational quality has been centered on only system inputs in terms of the provision of teachers, educators, teaching materials and other facilities, and on output in terms of trainees' achievement. Little or no attention is given to the teaching-learning process, the dimension which involves what really happens in the classroom. This study thus, aims at finding out the extent to which innovative approach to teaching and learning are employed in the Ethiopian primary teacher training classrooms, to identify the factors that affect its implementation, and to recommend better ways and means for further improvement. In conclusion the study found that traditional lecture methods, in which teachers talk and students listen, dominate most classrooms. The common obstacles to the employment of innovative methods of teaching as found out by this study are: the Ethiopian tradition of teaching, lack of institutional support, and learning resources, teachers' lack of expertise, inappropriate curricular materials and student teachers' lack of prior experience to actively participate in the teaching and learning process.
\end{abstract}

Key words: Quality, innovative, training, traditional 


\section{Background of the study}

Effective teaching and learning requires the use of different methodologies and strategies to meet the demands of the learners. The challenge is to find new ways and strategies to stimulate and motivate the creative abilities of today's generation who have varied set of orientations towards learning than the learners in the past. The traditional 'chalk and talk' approach with the students as recipients of knowledge may not be suitable for today's generation. The approach does not provide opportunities for students to interpret, organize and transfer knowledge to solve authentic problems. It is true that students must do more than just listening and note taking: They must read, write, discuss, or be engaged in solving problems. Most important, to be actively involved, students must engage in such higherorder thinking tasks as analysis, synthesis, and evaluation This is why in schools throughout the world there is a movement from learning that is made up of facts to a new model i.e. active-learning which emphasizes understanding, making connections in the world around us, collecting and using information in active manner (Leu, 2000:10).

We should think of active-learning first and for most in terms of students being intellectually active. By intellectually active we mean that teachers do not simply expect students to memorize and repeat facts. Teachers should expect students to use information critically and analytically. Nardos (2000:87) has pointed out that, in active learning the learners have a marked degree of freedom and control over the organization of learning activities. Usually these activities involve problem solving, inquiry and investigational work etc. Similarly, Aggarwal (1996:96) has mentioned that the basic purpose of education is to enable the learners to adapt in a society, which is full of problems. Not only social life is full of problems but there are problems and puzzling situations, which are normal features of a child's everyday life in school as well. Therefore, it is very important that problem solving skills should be encouraged in school learning. On the basis of this philosophy, the Education and Training policy of Ethiopia gives due emphasis to strengthening the individual's and society's problem solving capacities at all levels. As stated in the ETP: (1994:7) one of the objectives of education is "to develop the physical and mental potential and problem solving capacity of individuals by expanding basic education for all'.

\section{What is Active Learning?}

Active learning is a broad strategy that includes such techniques as substituting active-learning exercises for lecture, holding students' learning responsibility for the materials that have not been 
explicitly discussed in class assigning open ended problems and problems requiring critical or creative thinking that cannot be solved by following text examples, involving students in stimulating and role plays (Leu,2000).

The growth of active-learning as stated by Nunan (1991:11) “... signifies a paradigmatic shift from the transmission model of teaching to a process oriented, participatory model, seeing learners as active agents in their learning and teachers as researchers of their work." From the above argument supported by different scholars, it can be realized that active-learning is an essential element in education that have received a universal importance and it is a method of educating students that allow them to participate in class. It takes them beyond passive listeners and makes them to take some direction and initiative during the class.

\section{Teacher Education and Active Learning}

Frazee et al. (1995:80) state that the training of teachers is a crucial factor among others that affect the implementation of active learning, because the teacher is the final decision maker in regard to the actual learning opportunities provided to the students. The best designed curriculums as well as the poorest owe ultimate success or failure to the quality of the teachers' planning and implementation. In other words, according to Frazee et.al, if teachers lack knowledge of the teaching (active learning) method which requires new roles and commitment, implementation will be seriously hampered. Hence, provision of in-service teacher training is essential to acquaint teacher trainers with new teachinglearning methodologies, which are learner-oriented (active learning). If the expectation that learners should be the agents of change is taken seriously; the capacities this work requires of them should be considered carefully, current practice; pre- service and in- service teacher education should be examined critically, and ways to enhance teachers' learning across their careers should be explored more (Mukalel, et al, 1999:301). In line with this idea the Education and Training Policy of Ethiopia emphasizes new teacher education and training packages which are strongly practice- oriented at all levels of training, so that graduating teachers attain the necessary skills and a positive attitude in the application of variety of methods (ICDR, 1998: 40). In general, even though, the policy advocates active learning, there is a gap between theory and practice. Thus, teacher education needs to model class room teaching skills and methods that reflect and go in line with the Education and Training Policy. 


\section{The Problem}

In Ethiopia, as indicated in the Education and Training Policy document of the Transitional Government (TGE, 1994:4), the previous curriculum design and instructional processes suffered from old and traditional approach and therefore the current curriculum calls for emphasis on active learning and teaching. The policy document entitled as "Teacher Education System Overhaul (TESO) program which was introduced in 2003, among other major programs, one emphasizes the implementation of participatory, active- learning in the pre-service and in-service programs of teacher education (MoE, 2003:31). However, little attempt is made by the policy document and other subsequent education and training strategy documents to give elaborations and to indicate how it can be translated in the teachinglearning process at the classroom situation. Thus, learner-centered is most commonly understood for what it is not. Even education personnel at different levels are only phrasing around the term without mastering it and thereby providing support system for teachers, which is just only half the battle. Under such circumstances, curriculum designers, textbook writers, teacher training institutions, education experts, and teacher educators all followed their own way in translating learner-centered approach into practice. Thus this study attempts to find out how far the learner-centered approach is being employed in the Ethiopian primary teacher training institutes and what challenges teacher educators encounter while implementing it.

\section{The Research Questions}

The study attempted to answer the following research questions:

1. How is learner-centered approach being employed in the Ethiopian teacher training institutes?

2. To what extent does the Ethiopian traditional teaching affects the implementation of learnercentered approach in teacher training institutes?

3. Were the curricular, training materials and modules prepared in a way to facilitate learnercentered approach?

4. How far is the institutional environment conducive to utilizing the learner-centered approach?

5. Are teacher trainers (educators) equipped by the learner-centered approach during their training?

6. What is the trainees' view of being taught through active learning approach? 


\section{Purpose of the Study}

The main purpose of this study is to assess the quality of Ethiopian pre-service primary teacher education from the perspective of teaching strategies employed by teacher trainers. To this end, the study aims at analyzing the extent to which student-centered approach (active learning strategies) is perceived and practiced among teacher trainers and trainees. In addition, the study aims at exploring; the teacher trainers' perceptions and institution related variables militate against the implementation of active learning student-centered approach (active learning strategies). Ultimately, its findings are meant to help teacher educators, researchers, key educational policymakers and other education experts, to explore possibilities of developing more effective ways of utilizing active learning approach at intuition training level.

\section{Methodology}

This study is an explanatory study of quality of education in relation to quality of training, and a descriptive survey method is used in the study.

\section{Data Sources}

The sources of data were different groups of respondents that consist of college teacher educators and student teachers. Moreover, curriculum materials, training modules, and classrooms were used as data sources. Questionnaires and observation were used as instrument for collecting data.

\section{Sampling Procedure}

The research was conducted in Hawassa College of Teacher Education. The primary teacher education in Ethiopia is delivered in cluster modality. There are four cluster areas such as: language, social science, natural science and aesthetic. Two classrooms were randomly selected from each cluster. Two teachers and 15 students from each cluster (8 teachers and 60 students) were randomly selected to fill in the questionnaires. Furthermore, four training modules one from each cluster were selected and evaluated and observation of classrooms were made in order to substantiate the data.

\section{Presentation and Analysis of Data}

Before discussing the data related to the major questions, a summary of characteristics of the subjects is presented here. The intended information for this study has been gathered from two groups; namely, instructors and students of Hawassa Collage of Teacher Education. A total of 68 respondents were 
included in the study. Sixty of them were students and eight of them were instructors. Two instructors are qualified first degree holders and the rest six have second degrees. All of them have taken courses on general method of teaching. As far as training on active learning is concerned, almost all of them have special training and six of them have gone through the Higher Diploma Program. Students on the other hand, reported that they have started attending methodology courses in the collage and practicing active learning.

\section{Questionnaire Result}

Using the instructors' and students' questionnaire, responses about their perceptions of active learning were calculated and presented below. The data taken from the surveys were analyzed in line with the research questions. In analyzing the perceptions of instructors and students on active learning, the questionnaire entitled "Knowledge and experience on active learning" served as the primary source of information.

Table 1. Frequency Distribution of Data Collected on Perceptions of instructors

\begin{tabular}{|c|c|c|c|c|c|c|c|c|c|c|c|c|}
\hline \multirow[t]{2}{*}{ Items } & \multicolumn{2}{|c|}{$\begin{array}{l}\text { 1= strongly } \\
\text { disagree }\end{array}$} & \multicolumn{2}{|c|}{$2=$ disagree } & \multicolumn{2}{|c|}{ 3= undecided } & \multicolumn{2}{|c|}{ 4=agree } & \multicolumn{2}{|c|}{$5=$ strongly agree } & \multirow[t]{2}{*}{$\left(\_\sum \mathbf{x f}\right)$} & \multirow[t]{2}{*}{$\begin{array}{c}\mathbf{X}=\_\sum \mathbf{V x f} \\
\mathbf{N}\end{array}$} \\
\hline & $\mathbf{f}$ & $\%$ & f & $\%$ & $\mathbf{f}$ & $\%$ & f & $\%$ & f & $\%$ & & \\
\hline 1 & & & & & & & 4 & 50 & 4 & 50 & 36 & 4.5 \\
\hline 2 & 4 & 50 & 3 & 37.5 & 1 & 12.5 & & & & & 13 & 1.6 \\
\hline 3 & & & 4 & \begin{tabular}{l|l}
$\mathbf{5 0}$ \\
\end{tabular} & & & & & 4 & \begin{tabular}{l|l}
50 \\
\end{tabular} & 32 & 4.0 \\
\hline 4 & 8 & 100 & & & & & & & & & 8 & 8.0 \\
\hline 5 & & & & & & & 2 & 25 & 6 & 75 & 38 & 4.75 \\
\hline 6 & & & & & & & 2 & 25 & 6 & 75 & 38 & 4.75 \\
\hline 7 & & & & & & & 4 & 50 & 4 & 50 & 36 & 4.5 \\
\hline 8 & & & & & & & 5 & 62.5 & 3 & 37.5 & 35 & 4.4 \\
\hline 9 & & & & & & & $\mathbf{1}$ & 12.5 & 7 & 87.5 & 39 & 4.9 \\
\hline 10 & & & & & & & 5 & 62.5 & 3 & $\mathbf{3 7 . 5}$ & 35 & 4.4 \\
\hline 11 & & & & & & & 2 & 25 & 6 & 75 & 38 & 4.75 \\
\hline
\end{tabular}




\begin{tabular}{|c|c|c|c|c|c|c|c|c|c|c|}
\hline 12 & 2 & 25 & 6 & 75 & & & & & 14 & 1.8 \\
\hline 13 & 3 & $\mathbf{3 7 . 5}$ & 5 & 62.5 & & & & & 13 & 1.6 \\
\hline 14 & 4 & 50 & & & 4 & 50 & & & 20 & 2.5 \\
\hline 15 & & & & & $\overline{4}$ & 50 & 4 & $\mathbf{5 0}$ & 36 & 4.5 \\
\hline 16 & 4 & 50 & & & $\overline{4}$ & 50 & & & 20 & 2.5 \\
\hline $\begin{array}{l}\text { G. } \\
\text { Mean }\end{array}$ & & & & & & & & & & $\mathbf{3 . 5}$ \\
\hline
\end{tabular}

Active learning demands that teachers not only be experts in their fields, but also that they understand how students learn. It is a challenge for teachers to accept an active learning approach. As can be seen in table 1, the mean value of their responses (4.5) ranges from "Agree" to Strongly Agree." Hence, all the Instructors agreed on the idea (assumption) that current knowledge depends on the previous knowledge or understanding. On the other hand, item 2 of the same table says. "The teacher holds most of the knowledge necessary for the students." The mean value for this response is between 1 and 2 i.e. the instructors reflected their strong disagreement. This implies that all the instructors believe that students can also be sources of knowledge. Item 4 encountered strong disagreement by $100 \%$ of the instructors. This means that teaching facts alone is not enough to prepare students to understand their environment. For items 5 and 6, the mean values of the responses are 4.8 each. This indicates that instructors strongly agreed that teachers must prepare students to communicate. Almost all $(87.5 \%)$ of the respondents showed their strong agreement with the Item 9 which states that "Active learning offers opportunities for progress." -Furthermore, the mean value of the responses (4.9) strengthens the assumption raised. Item 13 says "Active learning is not economical in the use of instructional aids." A good percentage $(62.5 \%)$ of the respondents disagreed with the statement. Item 14 of the same table is about the requirement of active learning. Fifty percent of the respondents strongly disagreed with the idea and the other $50 \%$ of respondents supported the idea. But the mean value of the responses tends to disagree with the issue. The general analysis of all the items indicates that most instructors seem to have a positive attitude towards active learning. The grand mean value (3.5) of all the responses tend 
to support the values for agree. Hence, one can deduce that the groups of instructors have perceived active learning positively.

Table 2. Frequency Distribution of Data Collected on Perceptions of students

\begin{tabular}{|c|c|c|c|c|c|c|c|c|c|c|c|c|}
\hline \multirow[t]{2}{*}{ Items } & \multicolumn{2}{|c|}{$\begin{array}{l}1=\text { strongly } \\
\text { disagree }\end{array}$} & \multicolumn{2}{|c|}{$2=$ disagree } & \multicolumn{2}{|c|}{ 3= undecided } & \multicolumn{2}{|c|}{$4=$ agree } & \multicolumn{2}{|c|}{$5=$ strongly agree } & \multirow[t]{2}{*}{$\left(\_\sum \mathbf{x x f}\right)$} & \multirow[t]{2}{*}{$\mathbf{X}=\sum_{\mathbf{N}}^{\sum \mathbf{V x f}}$} \\
\hline & $\mathbf{f}$ & $\%$ & $\mathbf{f}$ & $\%$ & $\mathbf{f}$ & $\%$ & f & $\%$ & $\mathbf{f}$ & $\%$ & & \\
\hline 1 & 1 & 1.7 & 4 & 6.7 & 2 & 3.3 & 20 & 33.3 & 33 & 55 & 260 & 4.3 \\
\hline 2 & 13 & 21.7 & 33 & 55 & 5 & 8.3 & 7 & 11.7 & 2 & 3.3 & 132 & 2.2 \\
\hline 3 & 19 & 31.7 & 36 & 60 & 5 & 8.3 & & & & & 106 & $\overline{1.8}$ \\
\hline 4 & 6 & 10 & 11 & 18.3 & 1 & 1.7 & 11 & 18.3 & 33 & 55 & 240 & 4.0 \\
\hline 5 & & & & & 1 & 1.7 & 15 & 25 & 44 & 73.3 & 283 & 4.7 \\
\hline 6 & 5 & 8.3 & 2 & 3.3 & 9 & 15 & 25 & 41.7 & 19 & 31.7 & 231 & 3.9 \\
\hline 7 & & & & & 4 & 6.7 & 15 & 25 & 41 & 68.3 & 277 & 4.6 \\
\hline 8 & 23 & 38.3 & 21 & 35 & 5 & 8.3 & 7 & 11.7 & 4 & 6.7 & 128 & 2.1 \\
\hline 9 & & & & & 1 & 1.7 & 25 & 41.7 & 34 & 56.7 & 273 & 4.6 \\
\hline 10 & & & & & 2 & 3.3 & 18 & 30 & 40 & 66.7 & 278 & 4.6 \\
\hline 11 & & & & & 14 & 23.3 & 30 & 50 & 16 & 26.7 & 242 & 4.0 \\
\hline 12 & 16 & 26.7 & 20 & 33.3 & 7 & 11.7 & 8 & 13.3 & 9 & 15 & 154 & 2.6 \\
\hline 13 & 1 & 1.7 & 1 & 1.7 & 2 & 3.3 & 16 & 26.7 & 41 & 68.3 & 278 & 4.6 \\
\hline 14 & & & 2 & 3.3 & 3 & 5 & 20 & 33.3 & 35 & 58.3 & 268 & 4.5 \\
\hline $\begin{array}{l}\text { G. } \\
\text { Mean }\end{array}$ & & & & & & & & & & & & 38 \\
\hline
\end{tabular}

It is not only instructors' perception that affects the effective implementation of active learning instructional method. The perceptions and expectations of students also affect how learning is viewed and how teaching is organized. In relation to this, 14 items were presented to students to find out their perceptions and their prior knowledge about active learning. In table 2 item 1 states "I believe that learning depends on previous understanding”. In responding to this item $55 \%$ of the students showed 
their strong agreement whereas 33.5\% of them expressed their agreement. About $6.7 \%$ of them showed their disagreement and 1.7 said they strongly disagree with the idea. One of the assumptions of active learning says "The current knowledge depends on the previous understanding." In responding to the related item, a total of $88.5 \%$ the respondents showed their agreement. This indicates that the students have good understanding on the assumption forwarded. Item 3 states "lectures are the best ways of getting necessary knowledge." The statement is not supported by almost all the respondents. Sixty percent of the respondents showed their disagreement and $31.7 \%$ of them strongly disagreed with the idea. A small number (8.3\%) remained neutral. This seems to generalize that most of them have the assumptions that lecturing alone has nothing to do with their learning. But during observation, instructors use lectures in their classrooms in contrast to their responses in questionnaire. The reason for this may be the fear not to cover the portion. In item 5 of Table 2, the respondents were asked whether they believe active learning motivates them to learn. In responding to the item, the majority of the respondents $(73.3 \%)$ replied that they strongly agree with the idea, and $25 \%$ of them again showed their agreement. And the mean value of the responses indicates strong agreement. Learning by "doing" is a theme that many educators have stressed since John Dewey's convincing argument that students must be engaged in all active quests for learning new ideas. Students should be presented with real life problems and then helped to discover information required to solve them. In line with this, respondents were given an item which states "I believe that active learning is learning by doing." The majority of the respondents (68.3) answered that they strongly agree with the assumption. The mean value of the responses also shows that the respondents strongly agree. Item 10 which says: "I believe that active learning prepares us for participation." This issue was supported by the majority (66.7\%) of the respondents. The mean value of the responses is between "Agree" and "strongly agree". The grand mean value of the responses of the students is between "Undecided" and "Agree". Most instructors and students seem to have positive attitudes towards active learning. The grand mean values of instructors 3.5 and students 3.8 are tending to the value for "Agree". Hence, the two groups have perceived active learning positively. But, the observation result reflects that they do not implement active learning in their classrooms. The next part shows us a comparison of the instructors' and students' responses on the extent to which active learning is implemented. 
Table 3. A comparison of Percentages and Mean Values of Instructors and Students Indicating the Use of Active Learning Strategies

\begin{tabular}{|c|c|c|c|c|c|}
\hline \multirow[t]{2}{*}{ No } & \multirow[t]{2}{*}{ Items } & \multicolumn{2}{|l|}{ Instructors } & \multicolumn{2}{|l|}{ Students } \\
\hline & & $\begin{array}{lll}\text { Frequency } & \text { of } & \text { active } \\
\text { learning }(\%) & & \end{array}$ & $\begin{array}{l}\text { Mean } \\
\text { values }\end{array}$ & $\begin{array}{lll}\text { Frequency } & \text { of } & \text { active } \\
\text { learning }(\%) & & \end{array}$ & $\begin{array}{l}\text { Mean } \\
\text { values }\end{array}$ \\
\hline 1 & $\begin{array}{l}\text { Lecture/ } \\
\text { explanation }\end{array}$ & 12.5 & 3.1 & 41.7 & 4.1 \\
\hline 2 & Project work & 0.00 & 2.8 & 15 & 2.5 \\
\hline 3 & Problem solving & 0.00 & 4.0 & 31.7 & 3.1 \\
\hline 4 & Role playing & 50 & 3.5 & 20 & 3.2 \\
\hline 5 & Discussion & 25 & 4.6 & 20 & 3.9 \\
\hline 6 & Brainstorming & 0.00 & 5.0 & 23.3 & 3.4 \\
\hline 7 & Peer- teaching & 87.5 & 3.9 & 25 & 3.6 \\
\hline 8 & $\begin{array}{l}\text { Co-operative } \\
\text { learning }\end{array}$ & 75 & 4.5 & 8.5 & 2.9 \\
\hline 9 & Field trip & 0.00 & 1.3 & 1.7 & 1.6 \\
\hline 10 & Group work & 50 & 4.5 & 41.7 & 4.2 \\
\hline 11 & $\begin{array}{l}\text { Question and } \\
\text { answer }\end{array}$ & 37.5 & 4.6 & 30 & 3.9 \\
\hline 12 & Demonstration & 50 & 3.5 & 35 & 3.3 \\
\hline 13 & debating & 0.00 & 4.0 & 18.3 & 2.8 \\
\hline G.Mean & & 29.8 & 3.8 & 22.2 & 3.3 \\
\hline
\end{tabular}

A comparison between the responses of instructors and that of students was made to determine the relationship between their implementation of active learning in their classrooms. The researcher also compared the average responses and mean values of instructors and students for each of the specified questions as shown in table 3. According to the percentage and the mean values obtained, there is a difference in the implementation of active learning between instructors and students. For example, problem solving approach (one of the strategies) of active learning is reported by instructors to be frequently used whereas students pointed out that they use it sometimes. Brainstorming is again reported to be used always by the instructors but students said it is implemented only sometimes. The observation result however, revealed that both 'Problem solving' and 'Brain storming' are rarely used in the classrooms. The mean value for debating is (4.0) for instructors, and it is (2.8) for students; i.e. instructors reported that they implement it frequently but the students claimed that they see it 
sometimes. In looking at the grand mean of all the items (3.8) for the instructors, which is nearly close to "frequently", where as it is (3.3) by the students side which is only "sometimes", indicates that the implementations of active learning is not as expected to be.

Table 4. Percentage and Mean Values of Factors Affecting Instructors' Implementation of Active Learning

\begin{tabular}{|c|c|c|c|c|c|c|c|c|c|c|}
\hline \multirow[t]{2}{*}{ Items } & \multicolumn{2}{|c|}{$1=$ not serious } & \multicolumn{2}{|c|}{$2=$ undecided } & \multicolumn{2}{|c|}{$3=$ serious } & \multicolumn{2}{|c|}{$4=$ most serious } & \multirow[t]{2}{*}{$\left(\_\sum \mathbf{v x f}\right)$} & \multirow{2}{*}{$\mathbf{X}=\_\sum_{\mathbf{N}} \mathbf{V x f}$} \\
\hline & $\mathbf{f}$ & $\%$ & $\mathbf{f}$ & $\%$ & $\bar{f}$ & $\%$ & $\mathbf{f}$ & $\%$ & & \\
\hline $\mathbf{1}$ & & & 4 & 50 & 1 & 12.5 & 3 & 37.5 & 23 & 2.9 \\
\hline 2 & 4 & 50 & & & 3 & 37.5 & 1 & 12.5 & 17 & 2.1 \\
\hline 3 & 3 & 37.5 & 1 & 12.5 & 4 & 50 & & & 17 & 2.1 \\
\hline 4 & 5 & 62.5 & & & 1 & 12.5 & 2 & 25 & 16 & 2.0 \\
\hline 5 & 5 & 62.5 & & & 3 & 37.5 & & & 14 & 1.6 \\
\hline 6 & 3 & 37.5 & 2 & 25 & 1 & 12.5 & 2 & 25 & 18 & 2.3 \\
\hline 7 & $\overline{1}$ & 12.5 & & & 3 & 37.5 & 4 & 50 & 26 & 3.3 \\
\hline 8 & 3 & 32.5 & & & 1 & 12.5 & 4 & 50 & 22 & 2.6 \\
\hline 9 & 2 & 25 & 2 & 25 & 4 & 50 & & & 18 & 2.3 \\
\hline 10 & 4 & 50 & 1 & 12.5 & 3 & 37.5 & & & 15 & 1.9 \\
\hline 11 & 6 & 75 & 2 & 25 & & & & & $\mathbf{1 0}$ & 1.3 \\
\hline 12 & 2 & 25 & 2 & 25 & $\overline{3}$ & 37.5 & $\mathbf{1}$ & 12.5 & 19 & 2.4 \\
\hline $\begin{array}{l}\text { G. } \\
\text { Mean }\end{array}$ & & & & & & & & & & 2.3 \\
\hline
\end{tabular}

Table 4 shows factors affecting instructors' implementation of active learning. In this part there were twelve factors assumed to be affecting the implementation of active learning. Among these factors, the researcher has selected four of the factors to discuss. The factors are selected because the respondents indicate them to be those that significantly affect the implementation of active learning.

1 Students' lack of knowledge and experience in active learning $-50 \%$

2 The design of the training modules $-50 \%$

3 classroom environment $-50 \%$ 
4 Instructors belief and perception $-50 \%$

There is no question that knowledge, experience and perceptions are crucial factors in implementing active learning in classrooms. As can be seen from table 4, one of the hindering factors for the implementation of active learning is lack of students' knowledge and experience in active learning. This factor is supported by $50 \%$ of the instructors as a serious one. Another factor negatively affecting the implementation of active learning proposed by the instructors is the design of training modules. According to the data obtained from module evaluation, most of the modules are not engaging and do not have tasks and activities which promote active learning. It is also very difficult to apply active learning to large classes and in a situation where there is very limited or no access to resources which support active learning. In line with this, 50\% of the instructors identified that large classes and unsuitable classroom environment are the most serious factors affecting the implementation of active learning. Students on their part indicated factors that affect their participation in active learning.

Table 5. Percentage and Mean Values of Factors Affecting Student's Participation in Active Learning

\begin{tabular}{|c|c|c|c|c|c|c|c|c|c|c|}
\hline \multirow[t]{2}{*}{ Items } & \multicolumn{2}{|c|}{$1=$ not serious } & \multicolumn{2}{|c|}{$2=$ undecided } & \multicolumn{2}{|c|}{$3=$ serious } & \multicolumn{2}{|c|}{$4=$ most serious } & \multirow[t]{2}{*}{$\left(\_\sum \mathbf{x x f}\right)$} & \multirow{2}{*}{$\mathbf{X}=\_\underset{\mathbf{N}}{\sum_{\mathbf{N}} \mathbf{V x}}$} \\
\hline & $\mathbf{f}$ & $\%$ & f & $\%$ & f & $\%$ & f & $\%$ & & \\
\hline $\mathbf{1}$ & 14 & 23.3 & 6 & 10 & 17 & 28.3 & 23 & 38.3 & 169 & 2.8 \\
\hline 2 & 10 & 16.7 & 9 & 15 & 25 & 41.7 & 16 & 26.7 & 167 & 2.8 \\
\hline 3 & 33 & 55 & 13 & 21.7 & 7 & 11.7 & 7 & 11.7 & 108 & 1.8 \\
\hline 4 & 5 & 8.3 & 11 & 18.3 & 21 & 35 & 23 & 38.3 & 182 & 3.0 \\
\hline 5 & 16 & 26.7 & 17 & 28.3 & 16 & 26.7 & 11 & 18.3 & 142 & 2.4 \\
\hline 6 & 14 & 23.3 & 9 & 15 & 19 & 31.7 & 18 & 30 & 161 & 2.7 \\
\hline 7 & 21 & 35 & 10 & 16.7 & 12 & 20 & 17 & 28.3 & 145 & 2.4 \\
\hline 8 & 9 & 15 & 14 & 23.3 & 27 & 45 & 15 & 25 & $\mathbf{1 7 8}$ & 3.0 \\
\hline 9 & 17 & 28.3 & 11 & 18.3 & 19 & 31.7 & 13 & 21.7 & 148 & 2.5 \\
\hline 10 & 23 & 38.3 & 8 & 13.3 & 13 & 21.7 & 16 & 26.7 & 142 & 2.4 \\
\hline 11 & 7 & 11.7 & 16 & 26.7 & 24 & 40 & 13 & 25.7 & 163 & 2.7 \\
\hline 12 & 5 & 8.3 & 8 & \begin{tabular}{ll|}
13.3 \\
\end{tabular} & 35 & \begin{tabular}{|l|l|}
58.3 \\
\end{tabular} & 12 & 20 & 174 & 3.0 \\
\hline
\end{tabular}


It is no wonder that the shortage of time (item 2) in applying active learning is indicated as one of the major factors. This factor was selected as a serious one by $41.7 \%$ of the students. Some students' dominance and the design of the teaching module are also assumed to negatively affect the implementation of active learning. Accordingly $40 \%$ and $58.3 \%$ of the students proposed these factors respectively as serious problems. The other factor proposed as a hindering factor to implementing active learning is instructors' lack of knowledge and experience on active learning and their tendency to use lecture method. Thirty eight percent of the students identified this factor as the most serious problem in the use of active learning. Many researchers pointed out that time constraint is the major factor to consider in implementing active learning. For example, Capel et al (1995), explain that, some teachers dislike active learning simply because it brings an extra demand in the planning, preparation and evaluation. They believe that time table constraint pressurizes active learning. Likewise, $30 \%$ of the students pointed out that the time table is the most serious problem in the implementation of active learning.

\section{Observation Result}

The observation was conducted by the researcher and his co-observer and the result of observed cases were added up and presented in the following table.

\section{Table6. Classroom Condition}

\begin{tabular}{|l|l|l|l|l|l|}
\hline No & Item & \multicolumn{2}{l|}{ Yes } & \multicolumn{2}{l|}{ No } \\
\cline { 3 - 6 } & & No & $\%$ & No & $\%$ \\
\hline 1 & Is there enough sitting space for all & 7 & 78 & 2 & 22 \\
& students? & & & & \\
\hline 2 & Are the seats movable? & 7 & 78 & 2 & 22 \\
\hline 3 & Is the clas sroom lay- out arranged to & 3 & 33 & 6 & 67 \\
\hline 4 & Aacilitate active learning? & & & & \\
\hline 5 & Is the clas size appropriate? & - & - & 9 & 100 \\
\hline 6 & Is there enough space for movement between desks? & 1 & 11 & 8 & 89 \\
\hline
\end{tabular}

As depicted in table 6 the data obtained from classroom observation proved that the classroom condition and seating arrangement is not convenient to implement active learning. One major problem observed in the classroom is the lay-out of the classes. Majority (67\%) of the observation result 
indicates that the classroom lay-out is not arranged to facilitate active learning. The physical environments of the classroom do not reflect the required condition for active learning practices.

Table 7. Ins tructors' Activities

\begin{tabular}{|l|l|l|l|l|l|}
\hline No & Item & \multicolumn{2}{|l|}{ Yes } & \multicolumn{2}{l|}{ No } \\
\cline { 3 - 6 } & & No & $\%$ & No & $\%$ \\
\hline 1 & $\begin{array}{l}\text { Arranging students for different clas sroom } \\
\text { activity }\end{array}$ & 2 & 22 & 7 & 78 \\
\hline 2 & Clarifying the learning objectives & 1 & 11 & 8 & 89 \\
\hline 3 & $\begin{array}{l}\text { Giving direction about procedures and } \\
\text { activities }\end{array}$ & 1 & 11 & 8 & 89 \\
\hline 4 & $\begin{array}{l}\text { Using different instructional methods to } \\
\text { implement active learning }\end{array}$ & - & - & 9 & 100 \\
\hline 5 & $\begin{array}{l}\text { Encouraging students to become active } \\
\text { participant }\end{array}$ & 2 & 22 & 7 & 78 \\
\hline 6 & $\begin{array}{l}\text { Managing the class for active learning } \\
\text { implementation }\end{array}$ & 2 & 22 & 7 & 78 \\
\hline
\end{tabular}

In table 7 above, the classroom observation result indicates that majority of the activities expected to be practiced by the instructors were not observed. For instance, $100 \%$ of the observed classes did not show the use of different instructional methods to implement active learning. This indicates that the instructors implement the traditional/teacher fronted approach to teaching. The reasons for not applying the activities mentioned in table 7 may be lack of training on active learning and classroom conditions such as large class size and fixed desks.

Table 8. Activities of Students During the Lesson

\begin{tabular}{|l|l|l|l|l|l|}
\hline No & Item & \multicolumn{2}{|l|}{ Yes } & \multicolumn{2}{l|}{ No } \\
\cline { 3 - 6 } & & No & $\%$ & No & $\%$ \\
\hline 1 & $\begin{array}{l}\text { Students are participating in problem } \\
\text { solving activities }\end{array}$ & - & - & 9 & 100 \\
\hline 2 & Students are playing roles & & & & \\
\hline 3 & Giving direction about procedures and & 3 & 33 & 6 & 67 \\
\hline 4 & Students are discussing is sues in groups & 3 & 33 & 6 & 67 \\
\hline 5 & Students are practicing demonstration & 1 & 11 & 8 & 89 \\
\hline
\end{tabular}

The observation result of table 8 shows that students are not portraying the required behavior for their own learning. Among 9 observed sessions, only 33\% of them were observed discussing issues in their 
groups. The main reason for their poor participation may be the failure of their instructors to use active learning in their respective classes.

Table 9. Utilization of Instructional Materials

\begin{tabular}{|l|l|l|l|l|l|}
\hline \multirow{2}{*}{ No } & Item & \multicolumn{2}{l|}{ Yes } & \multicolumn{2}{l|}{ No } \\
\cline { 3 - 7 } & & No & $\%$ & No & $\%$ \\
\hline 1 & Are there charts, posters, diagrams, etc? & 2 & 22 & 7 & 78 \\
\hline 2 & Does the instructor use the instructional & - & - & 9 & 100 \\
\hline 3 & materials other than books, charts, posters? & & & & \\
\hline & Does the instructor illus trate ideas using & - & - & 9 & 100 \\
\hline
\end{tabular}

Availability of instructional materials in classroom is the major factor to enhance the whole process of education. Whereas in table, 9 the observation result indicates that in $78 \%$ of the observed classes, there was no instructional material. Moreover in $100 \%$ of the observed classes, the instructors do not use instructional materials. To sum up, the utilization of instructional materials in the observed classes was found to be at a minimum level. This might be due to lack of resources to be used.

Table 10. Classroom Evaluation

\begin{tabular}{|l|l|l|l|l|l|}
\hline No & Item & \multicolumn{2}{|l|}{ Yes } & \multicolumn{2}{l|}{ No } \\
\cline { 3 - 7 } & & No & $\%$ & No & $\%$ \\
\hline 1 & The instructor gives group work activities, & 3 & 33 & 6 & 67 \\
& for the learners to participate. & & & & \\
\hline 2 & The instructor follows up students' & 2 & 22 & 7 & 78 \\
& participation & & & & \\
\hline 3 & $\begin{array}{l}\text { The instructor elicits responses from the } \\
\text { students }\end{array}$ & 4 & 44 & 5 & 56 \\
\hline 4 & $\begin{array}{l}\text { The instructor evaluates students' group } \\
\text { cooperation }\end{array}$ & 4 & 44 & 5 & 56 \\
\hline 5 & The instructor checks and gives & & & & \\
\hline
\end{tabular}

Table 10 above indicates that all classroom activities are not well performed by the instructors. For example, many instructors do not give group work activities, ask questions or give exercises. Moreover almost all of the instructors do not follow up students' participation and activities. According to the 
observation result, only $33 \%$ of the instructors check and give constructive feedback to students' work. In an active learning classroom however, classroom assessment motivates the learners towards their learning. (TESO, 2003)

\section{Conclusion}

The Ethiopian government has taken quite a number of measures particularly aimed at improving quality of teacher education and training. However, despite the concern for quality education and training, it is found out that traditional lecture methods, in which teachers talk and students listen dominate most classrooms. The common obstacles and barriers to the employment of active learning in Ethiopian teacher education classrooms are the Ethiopian tradition of teaching and learning, lack of institutional support and learning resources, teachers' lack of expertise, inappropriate curricular materials and student teachers less preference to actively participate in learning due to lack of prior experience.

\section{References}

Aggarwal, J.C. (1996). Principles, Methods and Techniques of Teaching, New Delhi, S.n. Printers. Bennet et al (1996). Researching in to Teaching Methods in Colleges and Universities. London: Kogan Page.

Bonwell, C and Elison, A (2003). Active Learning Creating Excitement in the Classroom. Rhen: Grips Borich, G. D. (1984). Effective Teaching Methods. New York: Macmillan Publishing Company. Brad, Hayes (2000). Teacher Centered Instruction Vs Student Centered Instruction: Armuchee High School. American Government Schools (http://www.Secondaryschools.com/approach.html.

Bruner, J.S. (1966). Towards a Theory of Instruction. Harvard University Press.

Calahan, J. et. al. (1988). Teaching in the Middle Secondary Schools: Planning for Competence, New York: Macmillan.

Capel, et. al. (1995). Learning to Teach in the secondary Schools. London: Rutledge.

Chet, et al (1993) Promoting Active-learning Strategies for the College Classroom. Sanfransisco: Jossey. Base

Dale, E. (1969). Audiovisual Method in Teaching 3rd ed. New York: The Dryden Press.

Dary, N. and Terry, E. (1993). Reforming Open and Distance Education: Critical Reflection Practice. London: Kogan Page. 
Felder, D. (2000). Active Learning and Cooperative Learning. URL http://www.honolulu, hawail.edu/intrant/teachtip.htm.

Frazee, M.B. et al (1995). Integrated Teaching Methods: Theory Classroom Approach., and field based Connections. New York: Mc Graw Hill Inc.

Hailom Banteyerga (1998). "Explorations Towards An Alternative Model in Teacher Education Classroom in focus" in Quality Education in Ethiopia, Visions of 21st Century. Addis Ababa: IER.

ICDR. (1999). Teacher Education Hand Book. Addis Abba Finfine Printing and publishing. Leu, E (1998). Designing Integrated Curriculum Materials for Primary Education: a Paper Presented at the Workshop in Oromia Education Bureau. (Unpublished)

(2000). The Role of Curriculum Integration in Basic Education Tigrai Education

Bureau. (Unpublished)

MOE (2003). TESO Pre Service Committee a Notional Curriculum Guideline for pre-Service Teacher Education Programs. Addis Ababa (unpublished)

Moon, J.A. (2002). Reflection in Learning and Professional Development; Theory and Practice. UK Kogan Page Limited

Mukalel. J. (1998). Creative Approaches to Classroom Teaching, New Delhi: Discovery.

Nardos Abebe (2000) Issues and Methods and Materials in Teaching Primary School Subject Addis Ababa. AAU.

Nunan, D (1989) A Client Centered Approach to Teacher Development. ELT Journal 43/2

O’Hara, M. and O’Hara, J.A (1998) Cooperative Learning: A Paradigm for Learning in 21st Century American Secondary Education.

SNNP, REB (1997). "Curriculum Development: Controversies and Prospects.” Awassa: Unpublished. Squazzin, T. and Grann, M.V. (1998). Education Reform and Innovations in Namibia. Okahandja: Namibia.

Temecheqn Engida (2002) "Teaching Primary School Subject Using Learner- Centered Methodology in the Ethiopian Journal of Educational Researchers Association Vol. 1 No. 1. Addis Ababa. EERA.

TESO (2003) Teacher Education System Overhaul Programme. Addis Ababa.

Transitional Government of Ethiopia (1994) New Education and Training Policy (NETP) Addis Ababa.: EMPDA. 